\title{
Synthesis and Theoretical Investigation Using DFT of 2,3-Diphenylquinoxaline Derivatives for Electronic and Photovoltaic Effects
}

\author{
Dorota Zając ${ }^{1}\left[\right.$. Dariusz Przybylski ${ }^{2}$. Jadwiga Sołoducho ${ }^{1}$
}

Received: 9 January 2021 / Accepted: 26 May 2021 / Published online: 11 June 2021

(c) The Author(s) 2021

\begin{abstract}
Developing effective and low-cost organic semiconductors is an opportunity for the development of organic solar cells (OPV). Herein, we report the molecular design, synthesis and characterization of two molecules with D-A-D-A configuration: 2-cyano-3-(5-(8-(3,4-ethylenodioxythiophen-5-yl)-2,3-diphenylquinoxalin-5-yl)thiophen-2-yl)acrylic acid (6) and 2-cyano-3-(5-(2,3-diphenyl-8-(thiophen-2-yl)quinoxalin-5-yl)thiophen-2-yl)acrylic acid (7). Moreover, we investigated the structural, theoretical and optical properties. The distribution of HOMO/LUMO orbitals and the values of the ionization potential indicate good semiconducting properties of the compounds and that they can be a bipolar material. Also, the optical study show good absorption in visible light $\left(\lambda_{\text {abs }} 380-550 \mathrm{~nm}\right)$. We investigate the theoretical optoelectronic properties of obtained compounds as potential materials for solar cells.
\end{abstract}

Keywords 2,3-Diphenylquinoxaline · organic optoelectronic $\cdot$ Stille, Suzuki reaction · conjugated polymers · organic semiconductors

\section{Introduction}

Organic photovoltaics (OPV) is a technology that uses organic compounds to create a thin layer of semiconductor materials, due to their unique advantages, such as simple preparation and modification, low weight, flexibility, and cost-effectiveness. ${ }^{1-3}$ In addition, the use of organic semiconductors provides a wide selection of materials and great opportunities to improve their physicochemical properties thanks to chemical synthesis. Moreover, the processing of such semiconductors is simpler than in the case of silicon cells, as large amounts of material are not required and the process can be performed on various substrates. ${ }^{4,5}$ Currently, research aims at increasing the power conversion efficiency (PCE) of OPV. By developing or modifying new

Dorota Zając

dorota.zajac@pwr.edu.pl

1 Faculty of Chemistry, Wrocław University of Science and Technology, Wybrzeże Wyspiańskiego 27, 50-370 Wrocław, Poland

2 Faculty of Microsystem Electronics and Photonics, Wrocław University of Science and Technology, Długa 61-65, 53-633 Wrocław, Poland organic semiconductors, the properties and morphology of the device are improved. Previous research reported 17.05\% PCE for polymer solar cells. ${ }^{6}$ However, despite the progress achieved in the field of OPV, attempts are still being made to solve the limitations resulting from poor mobility of charge carriers and unsatisfactory light absorption. ${ }^{7-9}$ More bipolar (donor-acceptor, D-A) material development reports are available. Recent studies report that in order to obtain bipolar characteristics in the molecule, the energy levels must be adjusted so that the HOMO orbital has energy $\geq 5.6$ $\mathrm{eV}$, and the LUMO orbital has energy around $3.15 \mathrm{eV} .^{10,11}$ These are the basic conditions for the injection/charge transport of both electrons and holes under ambient conditions. Typically, thiophene, triphenylamine and carbazole derivatives are used as D components, while benzothiadiazole, diketopyrrolopyrrole and quinoxaline derivatives are used as A components for the construction of conjugated polymers of the D-A type and in different arrangements of donor and acceptor molecules throughout the molecule, e.g. D-A-D-A-D, A-D-A-D-A. ${ }^{12-20}$ 2,3-Diphenylquinoxaline (DPQ) is an efficient electron withdrawing unit due to its suitable electronegativity, stable quinoid structure and easy synthesis. It reduces charge recombination by inhibiting intermolecular aggregation due to two separate phenyl rings 
attached to a quinoxaline unit. Introducing DPQ as a helper acceptor can improve donor electron distribution, redshift the absorption spectra, fine-tune energy levels and improve photostability. ${ }^{21-24}$

Molecular modeling has become a useful tool to investigate molecular and photoelectrochemical properties using quantum chemical computations. Density functional theory (DFT) with Becke3-Lee-Yang-Parr (B3LYP) method is one of the most accurate tools used to analyze an organic system's structural features and its properties. ${ }^{16,25,26}$ The observation of theoretical study, however, should be treated with caution, since the orbital energies are basis set dependent. Our previous experience shows that the physicochemical properties of heterocyclic compounds synthesized by our research group are predicted with great accuracy by the ccpVDZ base. ${ }^{27-29}$

In this work, considering the important aspects of molecules with the D-A-D-A configuration in electron transport and their solid state application in optoelectronic devices, we designed and synthesized two DPQ-based compounds in which electron-donating ethylenedioxythiophene or thiophene was combined with electron accepting DPQ. Additionally, through thiophene as a linker, we connected cyanoacrylic acid to DPQ as an additional electron acceptor and an anchor group (Scheme 1). The design of the compounds was based on the following considerations: (i) thiophene and ethylenedioxythiophene are used as an electron donor to obtain more positive HOMO energy levels; (ii)

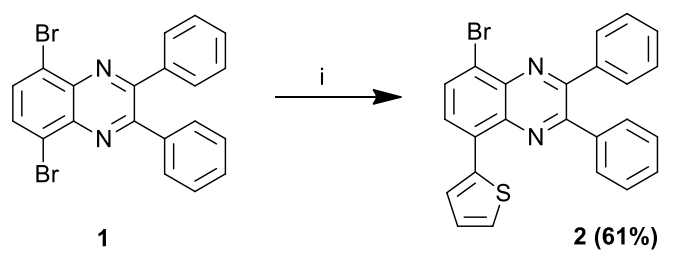<smiles>CC#CC=Cc1cc(Br)c2nc(-c3ccccc3)nc(-c3ccccc3)c2n1</smiles><smiles>CC(C)(C)Oc1ccc(Br)s1</smiles><smiles>O=Cc1ccc(-c2ccc(-c3scc4c3OCCO4)nc2-c2ccccc2)nc1-c1ccccc1</smiles><smiles>O=Cc1ccc(-c2ccc(-c3cccs3)c3nc(-c4ccccc4)c(-c4ccccc4)nc23)s1</smiles><smiles>[Y][V]</smiles><smiles>[Y]C1CCCCC1</smiles><smiles>N#CC(=O)C(=O)O</smiles><smiles>N#C/C(=C\c1ccc(-c2ccc(-c3cccs3)c3nc(-c4ccccc4)c(-c4ccccc4)nc23)s1)C(=O)O</smiles>

Scheme 1 Synthesis of DPQ derivatives $(\mathbf{6}, 7): \boldsymbol{i}$ : 2-(tributylstannyl)tiophene, $\mathrm{PdCl}_{2}\left(\mathrm{PPh}_{3}\right)_{2}$, THF, $\mathrm{N}_{2}$, reflux, $24 \mathrm{~h}$; $i$ : DMF, $\mathrm{POCl}_{3}$, dichloroethane, $\mathrm{N}_{2}, 24 \mathrm{~h}$; iii: Stille: (A) 2-(tributylstannyl)ethylenodioxythiophene, $\mathrm{PdCl}_{2}\left(\mathrm{PPh}_{3}\right)_{2}, \mathrm{THF}, \mathrm{N}_{2}$, reflux, $72 \mathrm{~h}$; Suzuki: (B) 5-(4,4,5,5-tetramethyl-1,3,2-dioxaborolan-2-yl)-2-thiophene, $\mathrm{K}_{2} \mathrm{CO}_{3}$, $\mathrm{PdCl}_{2}\left(\mathrm{PPh}_{3}\right)_{2}$, toluene, $\mathrm{H}_{2} \mathrm{O}, \mathrm{MeOH}, \mathrm{N}_{2}$, reflux, $48 \mathrm{~h}$; iv: toluene, cyanoacetic acid, piperidine, $\mathrm{N}_{2}, 24 \mathrm{~h}$. 
2,3-diphenylquinoxaline is used as an electron withdrawing separator; (iii) thiophene is introduced as a donor and subsequent separator to extend conjugation of the entire system; (iv) a cyanoacrylic acid unit is used as an electron acceptor that acts as an anchor group to the substrate. Thanks to this structure, it is possible to extend the length of the molecule's conjugation and to extend the absorption. An additional acceptor in the form of DPQ may facilitate efficient charge transfer from the ground state to the excited state. Photovoltaic properties of solar cells based on 2-cyano-3-(5-(8- $(3,4-$ ethylenodioxythiophen-5-yl)-2,3-diphenylquinoxalin-5-yl) thiophen-2-yl)acrylic acid (6) and 2-cyano-3-(5-(2,3-diphenyl-8-(thiophen-2-yl)quinoxalin-5-yl)thiophen-2-yl)acrylic acid (7) have been studied in this work. B3LYP/cc-pVDZ methods are used to obtain geometries and optimize the electronic properties, optical and photovoltaic parameters for 2,3-diphenylquinoxaline derivatives. We wanted to investigate a system that already has both electron donors and acceptors in its structure as a potential bipolar material, and find whether such a structural motif has the appropriate optoelectronic properties to use these compounds as active layers in cells.

\section{Results and Discussion}

\section{Synthesis}

The synthetic methods of two products, 2-cyano3-(5-(8-(3,4-ethylenodioxythiophen-5-yl)-2,3-diphenylquinoxalin-5-yl)thiophen-2-yl)acrylic acid (6) and 2-cyano-3-(5-(2,3-diphenyl-8-(thiophen-2-yl)quinoxalin5-yl)thiophen-2-yl)acrylic acid (7) are present in Scheme 1. The 3,4-ethylenedioxythiophene was monostannylated to 2-(tributylstannyl)-3,4-ethylenedioxythiophene with 99\% yield with $\mathrm{SnMe}_{3} \mathrm{Cl}$ in $\mathrm{THF}$ at $-80^{\circ} \mathrm{C}$. The first step of the reaction was a synthesis of the compound 2 (Stille coupling), which was based on the modification of the structure by adding a thiophene moiety, so that the presence of a sulfur atom in the ring had an activating effect by S-coordinating to lithium, followed by proton detachment by a butyl group during the $n$-BuLi metallation reaction. This was converted to the key precursor 5-(8-bromo-2,3-diphenylquinoxalin5-yl)thiophene-2-carbaldehyde (3) through Vilsmeier-Heck reaction with $16 \%$ yield. Next step were palladium-catalyzed carbon-carbon bond formation reactions, i.e. Suzuki or Stille (5-(2,3-diphenyl-8-(thiophen-2-yl)quinoxalin-5-yl) thiophene-2-carbaldehyde (4) and 5-(8-(3,4-ethylenodioxythiophen-5-yl)-2,3-diphenylquinoxalin-5-yl)thiophene2 -carbaldehyde (5)). Finally, compounds $\mathbf{4}$ or $\mathbf{5}$ in reaction with cyanoacetic acid and piperidine, following the Knoevenagel condensation protocol, yielded 6 and 7 respectively. All the synthesized compounds were purified further by using a column chromatography technique. The molecular structures of these target compounds and their intermediates were established by using different spectroscopic tools.

\section{Theoretical Study}

Density functional theory (DFT) calculations based on the B3LYP/cc-pVDZ level were performed to obtain the optimized molecular geometries as well as the highest occupied molecular orbital (HOMO) and the lowest unoccupied molecular orbital (LUMO) levels of 2-cyano-3-(5-(8-(3,4ethylenodioxythiophen-5-yl)-2,3-diphenylquinoxalin-5-yl) thiophen-2-yl)acrylic acid (6) and 2-cyano-3-(5-(2,3-diphenyl-8-(thiophen-2-yl)quinoxalin-5-yl)thiophen-2-yl)acrylic acid (7). The xyz coordinates of the optimized structures of $\mathbf{6}$ and $\mathbf{7}$ are included in supplementary material. The calculated HOMO and LUMO levels are delocalized over the molecular backbones (Fig. 1). In ambipolar materials, both hole and electron charge carriers are injected and transported to HOMO-LUMO energy levels. Consistent with the assumptions for ambipolar materials, compounds $6(\mathrm{HOMO}=-5.60 \mathrm{eV}, \mathrm{LUMO}=-3.04 \mathrm{eV})$ and $7(\mathrm{HOMO}$ $=-5.83 \mathrm{eV}, \mathrm{LUMO}=-3.16 \mathrm{eV}$ ) have a HOMO orbital $\geq-5.60 \mathrm{eV}$,

and a LUMO orbital around $-3.15 \mathrm{eV}$ (Table I). This suggests that they are compounds with good conductive properties.

Furthermore, the lower ionization potential (IP) of $\mathbf{6}$ proves stronger electron-donating abilities than 7 . The higher LUMO energy level of the $\mathbf{6}(-3.04 \mathrm{eV}$ for $\mathbf{6}$ and $-3.16 \mathrm{eV}$ for 7 ) makes the barrier of electron injection smaller, and thus the charge injection capacity is greater. Comparing derivatives $\mathbf{6}$ and $\mathbf{7}$ suggests that $\mathbf{6}$ is a system with a better charge transfer (CT). The theoretically calculated absorption maxima $\left(\lambda_{\max }\right)$ of the investigated molecules $\mathbf{6}$ and $\mathbf{7}$ are summarized in Table I.

Compound 6 has the greater $\Delta G^{\text {inject }}(-0.73 \mathrm{eV})$ while 7 has the smaller value $(-0.60 \mathrm{eV})$ (Table II.). Both $\Delta G^{\text {inject }}$ obtained is negative for every dye, so the $\mathrm{e}^{-}$injection from the composed to $\mathrm{TiO}_{2}$ is impulsive.

This result according to LHE of the $\mathbf{6}$, shows that the structure of compound $\mathbf{6}$ extends the photocurrent reply, in comparison to compound 7. Compared with 7, the larger $f$ of $\mathbf{6}$, leading to the higher LHE ( 0.82 for $\mathbf{6}$ and 0.81 for 7 ), compensates well for its green-shift adsorption spectrum. Results show that 6 have the higher $V_{\text {oc }}(0.96 \mathrm{eV})$ than compound $7(0.84 \mathrm{eV})$, thus the $\mathrm{e}^{-}$injection is more effective due to the higher excited state linked to the semiconductor conduction band edge. Consequently, compound 6 presents favorable properties to potential application to organic solar cells because of the relatively similar LHE, larger $\Delta G^{\text {inject }}$, and $V_{\text {oc }}$. 


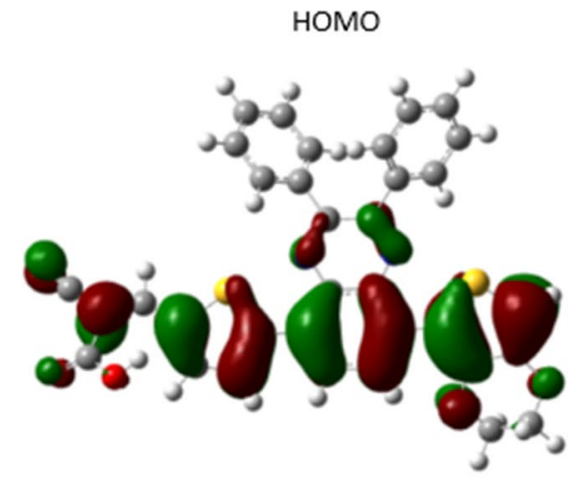

HOMO

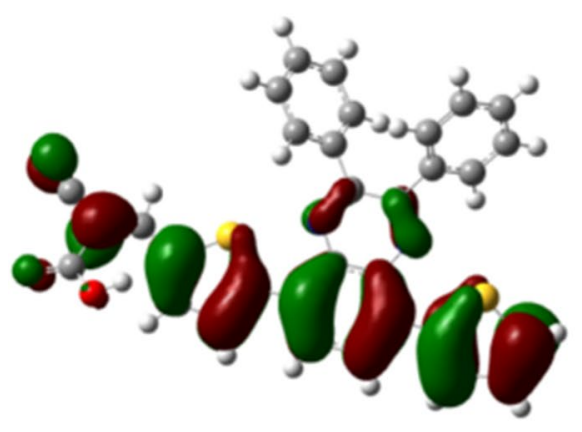

LUMO

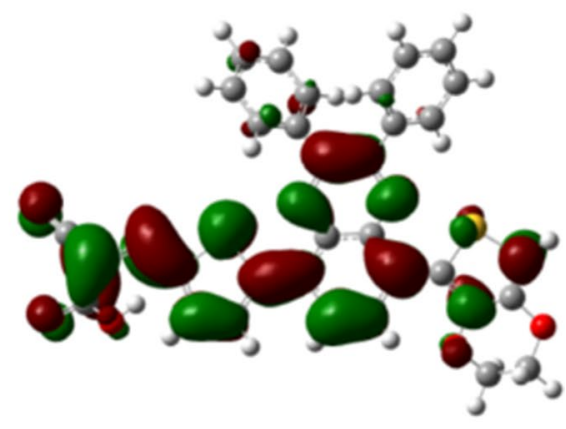

LUMO

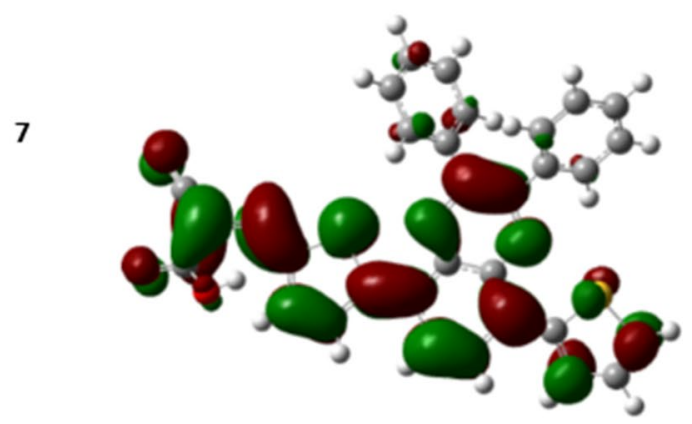

Fig. 1 Frontier molecular orbitals of 6 and 7.

Table I Theoretical properties of investigated compounds: Eg-bandgap; IP—ionization potential; EA—electron affinity; $\lambda_{\text {max }}$-absorption maxima; f-oscillator strength

\begin{tabular}{lllllllll}
\hline Compound & HOMO $(\mathrm{eV})$ & LUMO $(\mathrm{eV})$ & $\mathrm{Eg}(\mathrm{eV})$ & $\mathrm{IP}(\mathrm{eV})$ & $\mathrm{EA}(\mathrm{eV})$ & $\lambda_{\max }(\mathrm{nm})$ & $f$ & Transition \\
\hline $\mathbf{6}$ & -5.60 & -3.04 & 2.56 & -6.20 & -2.09 & 532 & 0.74 & $\mathrm{H}-\mathrm{L}$ \\
$\mathbf{7}$ & -5.83 & -3.16 & 2.67 & -6.45 & -2.20 & 510 & 0.73 & $\mathrm{H}-\mathrm{L}$ \\
\hline
\end{tabular}

Table II Calculated electrochemical parameters for investigated compounds: $E^{\text {dye }}$ and $E^{\text {dye* }}-$ oxidation potential energy of the composed in the ground and excited state; LHE-light-harvesting efficiency;

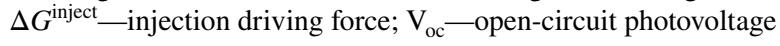

\begin{tabular}{llllll}
\hline Compound & $E^{\text {dye }}(\mathrm{eV})$ & $E^{\text {dye* }}(\mathrm{eV})$ & $\Delta G^{\text {inject }}(\mathrm{eV})$ & $\operatorname{LHE}$ & $V_{\text {oc }}(\mathrm{eV})$ \\
\hline $\mathbf{6}$ & 5.60 & 3.27 & -0.73 & 0.82 & 0.96 \\
7 & 5.83 & 3.40 & -0.60 & 0.81 & 0.84 \\
\hline
\end{tabular}

The $V_{\mathrm{oc}}$ can be calculated by the analytical equation: $V_{\mathrm{oc}}$ $=E_{\mathrm{LUMO}}-E_{\mathrm{CB}}{ }^{25} \mathrm{E}_{\mathrm{CB}}$ : reduction potential of the conduction band of $\mathrm{TiO}_{2}$. So, in this study, we use $E_{\mathrm{CB}}=-4.0$ eV for $\mathrm{TiO}_{2}{ }^{30}$

As shown in Fig. 2. the investigated molecules 6 and 7 show wide peaks (300-700 nm), corresponding to $\pi-\pi^{*}$ transition and charge-transfer process within the molecules in the visible light region. The combination of good absorption and ambipolar electronic properties suggests that they can be used as well in OLED as OPV.

\section{Optical Properties}

Figure 3 represents the corresponding absorption spectra of solutions 6 and 7 in THF. As can be noticed, both 6 (blue curve) and 7 (green curve) present an absorption peak situated between $285 \mathrm{~nm}$ and $550 \mathrm{~nm}$. Compound 6 has an enlarged absorption spectrum in comparison to compound $\mathbf{7}$, which may be due to the higher electron-donating properties of ethylenedioxythiophene than of thiophene ring.

The optical properties of the organic films of $\mathbf{6}$ and 7 deposited on the PEDOT:PSS/ITO/Glass substrates were evaluated in terms of plotting their transmission spectra in a spectral range between $285 \mathrm{~nm}$ and $1200 \mathrm{~nm}$ (Fig. 4). It can be seen that for the range from $285 \mathrm{~nm}$ to $380 \mathrm{~nm}$, the characteristics are similar for both samples. For the range from 

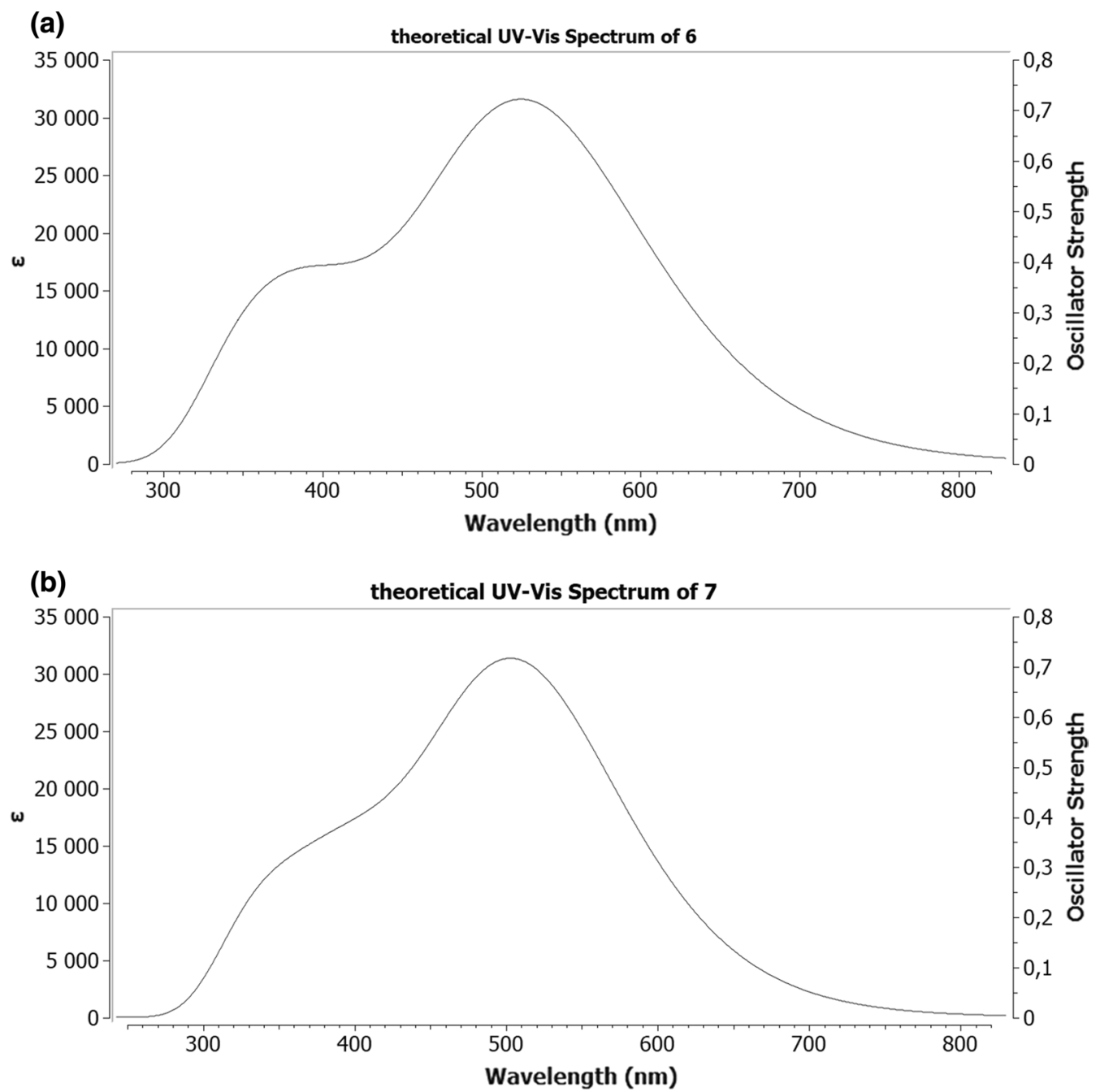

Fig. 2 Theoretical UV-Vis spectrum: (a) of compound 6; (b) of compound 7.

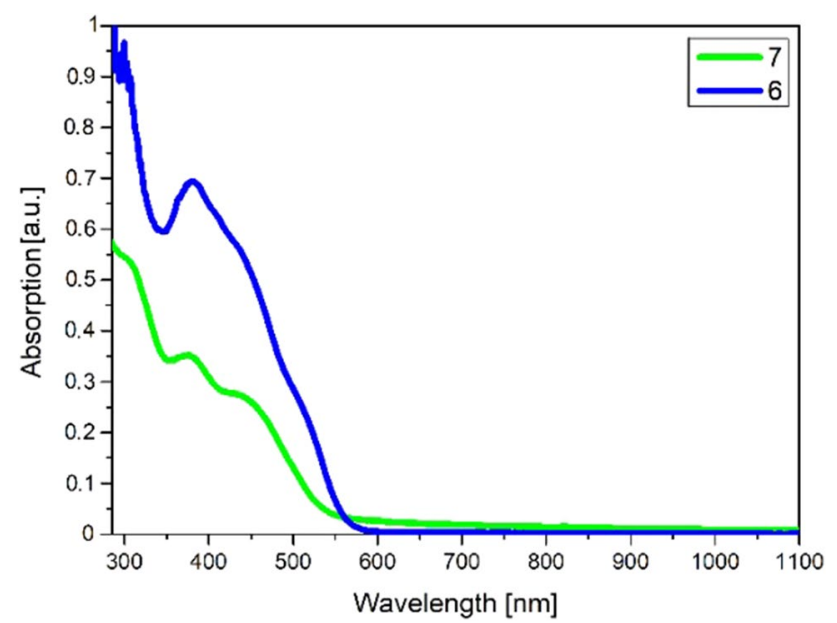

Fig. 3 Absorption spectra for solutions 6 and 7 in THF.

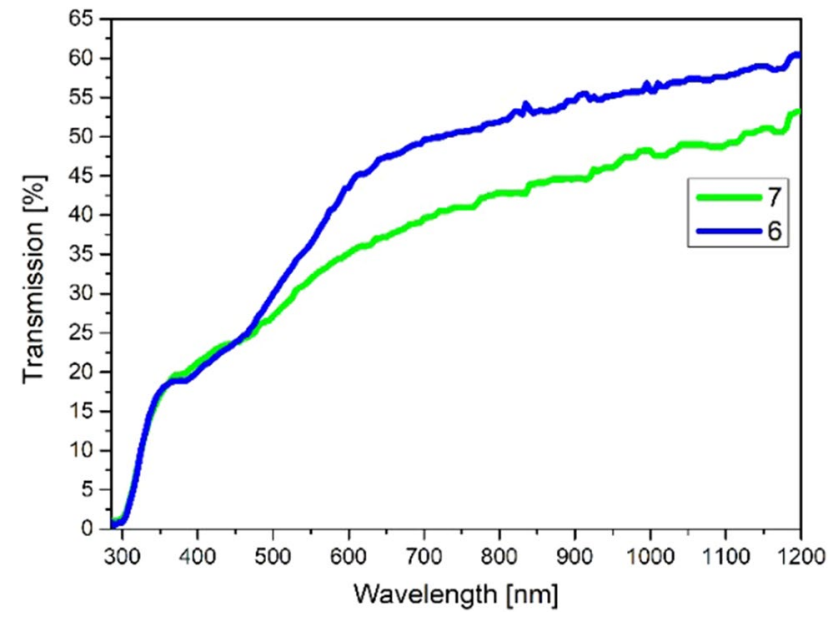

Fig. 4 Transmission spectra for active layers: 6/PEDOT:PSS/ITO/ Glass (blue) and 7/PEDOT:PSS/ITO/Glass (green) (Color figure online). 
285 to $300 \mathrm{~nm}$, the transmission is $0 \%$, because the glass is not transparent under $300 \mathrm{~nm}$ wavelength. Above $480 \mathrm{~nm}$, the transmission of sample $\mathbf{6}$ increases in comparison to data for sample 7. Sample 6 is more transparent to light than sample 7. The highest transmission values are reached at $1200 \mathrm{~nm}$.

\section{Materials and Methods}

\section{Details of Theoretical Studies}

The theoretical studies were performed by applying the density functional theory (DFT) ${ }^{31}$ The calculations were performed utilizing the B3LYP functional ${ }^{32-34}$ and standard cc-pVDZ atomic basis set. ${ }^{35}$ The absorption spectra we studied applying time dependent DFT (TDDFT). ${ }^{36}$ All the calculations were carried out using the Gaussian 16 suite of codes. ${ }^{37}$ The molecular graphics were produced applying GausView program. ${ }^{38}$

\section{Sample Characterization}

The spin-coating process was performed using a Speciality Coating Systems Spin Coater G3P-8. The thickness of layers was measured using a Precision Measurement System Form Talysurf 120 made by Taylor Hobson Precision. The measuring probe with a sphere with $2 \mu \mathrm{m}$ diameter was used. The analysis of the profiles of the samples surface profiles was performed using Talysurf software. Absorption spectra measurements for solutions $\mathbf{6}$ and $\mathbf{7}$ in THF were performed using a Optizen Aplha Hybrid Mecasys spectrophotometer. Absorption spectra were recorded at room temperature in the wavelength range of $280-1100 \mathrm{~nm}$. Quartz cuvettes were used. The transmission of radiation for samples were measured using WVASE Ellipsometer in function of spectrophotometer (the light source was a xenon arc lamp). The range of wavelength was from $285 \mathrm{~nm}$ to $1200 \mathrm{~nm}$. The measurement was recorded at room temperature.

\section{Chemistry}

Indium tin oxide coated glass slide, square (ITO) (surface resistivity $8-12 \Omega / s q$ ), poly(3,4-ethylenedioxythiophene)poly(styrenesulfonate) (1.3 wt.\% dispersion in $\mathrm{H}_{2} \mathrm{O}$, conductive grade) (PEDOT:PSS), aluminum (powder, 91\%), n-Butyllithium (2.5 $\mathrm{M}$ in hexane), 5-(4,4,5,5-tetramethyl-1,3,2-dioxaborolan-2-yl)-2-thiophene (98\%), 3,4-ethylenodioxythiophene (97\%), 2-(tributylstannyl)tiophene (98\%), bis(triphenylphosphine)palladium (II) dichloride (98\%), cyanoacetic acid (99\%), piperidine (99\%), anhydrous N,N-dimethylformamide (99.8\%), phosphorus(V) oxychloride (99\%) were purchased from Aldrich.
5,8-Dibromo-2,3-diphenylquinoxaline (98\%) was purchased from TCI Europe. Anhydrous potassium carbonate (99\%) was received from Chempur. Anhydrous tetrahydrofuran was purchased from $\mathrm{POCH}$. Tetrahydrofuran was dried over $\mathrm{Na} /$ benzophenone ketal before use. Other commercially available substances and reagents were used without any prior purification. Preparative column chromatography was performed on the glass column with Acros Organics silica gel for chromatography, $0.035-0.075 \mathrm{~mm} 60 \AA .{ }^{1} \mathrm{H}$ NMR and ${ }^{13} \mathrm{C}$ NMR spectra were recorded in deuterated chloroform $\left(\mathrm{CDCl}_{3}\right)$ on Bruker Avance III $400 \mathrm{MHz}$ Instruments or on Bruker Avance II 600 Instruments, respectively. Chemical shifts were locked to chloroform $\delta \mathrm{H} 7.26(\mathrm{~s})$ and $\delta \mathrm{C} 77.16(\mathrm{t})$ signals. The molecular weights of the products were determined using a Bruker micrOTOF-Q spectrometer, FWHM$17500,20 \mathrm{~Hz}$. The percentage composition of the elements was measured on a vario EL cube analyzer from Elementar Americas.

\section{Preparation of 5-bromo-2,3-diphenyl-8-(thiophen-2-yl) quinoxaline (2)}

Bis(triphenylphosphine)palladium (II) dichloride $\left(\mathrm{PdCl}_{2}\left(\mathrm{PPh}_{3}\right)_{2}\right)(0.32 \mathrm{~g}, 0.450 \mathrm{mmol})$ was added at room temperature under nitrogen atmosphere to a mixture of $\mathbf{1}$ $(1.00 \mathrm{~g}, 2.27 \mathrm{mmol})$ and 2-(tributylstannyl)tiophene $(0.89$ $\mathrm{g}, 2.39 \mathrm{mmol})$ in anhydrous THF $(50 \mathrm{~mL})$. The resulting mixture was refluxed with stirring for $48 \mathrm{~h}$. Then the reaction mixture was concentrated under reduced pressure, diluted with water, and extracted with EtOAc. The extract was washed with brine, dried over $\mathrm{MgSO}_{4}$, and concentrated. The residue was purified by silica gel column chromatography (hexane-EtOAc in the gradient of polarity) to give $\mathbf{2}$ $(0.61 \mathrm{~g}, 61.4 \%)$ as a yellow oil. According to ${ }^{39}$

-1 H NMR (400 MHz, $\left.\mathrm{CDCl}_{3}\right) \delta(\mathrm{ppm}): \delta 8.01\left(\mathrm{dd}, J_{l}=8.4\right.$ $\left.\mathrm{Hz}, J_{2}=34.4 \mathrm{~Hz}, 1 \mathrm{H}\right), 7.84(\mathrm{~d}, J=3.6 \mathrm{~Hz}, 1 \mathrm{H}), 7.75-7.64$ (m, 4H), 7.52 (t, J=5.4 Hz, 1H), 7.45-7.33 (m, 7H), 7.169 (t, $J=4.4 \mathrm{~Hz}, 1 \mathrm{H})$.

${ }^{13} \mathbf{C}$ NMR $\left(151 \mathrm{MHz}, \mathrm{CDCl}_{3}\right) \delta(\mathrm{ppm}): \delta 154.2,153.2$, $152.7,151.8,139.4,138.8,138.4,138.3,138.2,138.0$, $133.2,132.8,130.6,130.3,129.7,129.4,129.3,128.5$, $128.3,127.4,126.8,126.5,123.8,122.5$.

-MS (m/z): $\left[\mathrm{M}^{+}\right] 442.0135$

Elemental analysis: calc. (\%) C: 65.02 ; H: 3.41; N: 6.32; S: 7.23; found: C:65.07; H:3.36; N:6.27; S:7.20.

\section{Preparation of 5-(8-bromo-2,3-diphenylquinoxalin-5-yl) thiophene-2-carbaldehyde (3)}

DMF (1.12 mL, $14.52 \mathrm{mmol})$ was added to a three-necked flask, under a nitrogen atmosphere. It was cooled in an ice bath, then $\mathrm{POCl}_{3}(0.25 \mathrm{~mL}, 2.70 \mathrm{mmol})$ was added dropwise 
and stirred for $40 \mathrm{~min}$ at room temperature. Compound $\mathbf{2}$ $(0.92 \mathrm{~g}, 2.08 \mathrm{mmol})$ was dissolved in $30 \mathrm{~mL}$ of dichloroethane and added to the mixture. The resulting mixture was refluxed with stirring for $24 \mathrm{~h}$. The reaction was terminated by adding $10 \mathrm{~mL}$ of cold water and $5 \mathrm{~mL}$ of $2 \mathrm{M} \mathrm{NaOH}$. The reaction mixture was then filtered under reduced pressure, and the filtrate was extracted with chloroform. The crude product was purified by column chromatography (hexaneEtOAc in the gradient of polarity) to give $3(0.152 \mathrm{~g}, 16.0 \%)$ as an orange solid. According to ${ }^{39}$

- ${ }^{1}$ H NMR (400 MHz, $\left.\mathrm{CDCl}_{3}\right) \delta$ (ppm): $\delta 9.97(\mathrm{~s}, 1 \mathrm{H})$, $8.057\left(\mathrm{dd}, J_{l}=8.00 \mathrm{~Hz}, J_{2}=33.6 \mathrm{~Hz}, 2 \mathrm{H}\right), 7.85(\mathrm{dd}$, $\left.J_{l}=4.4 \mathrm{~Hz}, J_{2}=34.8 \mathrm{~Hz}, 2 \mathrm{H}\right), 7.69-7.67(\mathrm{~m}, 4 \mathrm{H}), 7.43-$ $7.34(\mathrm{~m}, 6 \mathrm{H})$.

- ${ }^{13}$ C NMR (151 MHz, $\left.\mathrm{CDCl}_{3}\right) \delta$ (ppm): $\delta 182.1,155.7$, $154.2,153.4,152.1,140.0,139.3,138.6,138.4,138.2$, $137.8,133.5,132.6,130.2,130.0,129.9,129.5,128.9$, $128.7,128.4,127.0,126.5,126.2,124.0,123.5$.

- $\mathbf{M S}(\mathrm{m} / \mathrm{z}):\left[\mathrm{M}^{+}\right] 472.0218$

- Elemental analysis: calc. (\%) C: 63.70; H: 3.21; N: 5.94; S: 6.80; found: C:63.66; H:3.26; N:5.90; S:6.78.

\section{Preparation of 5-(2,3-diphenyl-8-(thiophen-2-yl)quinoxa- lin-5-yl)thiophene-2-carbaldehyde (4)}

Bis(triphenylphosphine)palladium (II) dichloride $\left(\mathrm{PdCl}_{2}\left(\mathrm{PPh}_{3}\right)_{2}\right)(0.117 \mathrm{~g}, 0.100 \mathrm{mmol})$ was added at room temperature to a mixture of $\mathbf{3}(0.238 \mathrm{~g}, 0.505 \mathrm{mmol})$, potasium carbonate $(0.209 \mathrm{~g}, 1.51 \mathrm{mmol})$, and 5-(4,4,5,5-tetramethyl-1,3,2-dioxaborolan-2-yl)-2-thiophene (0.192 g, $0.656 \mathrm{mmol})$ in toluene $(30 \mathrm{~mL}), \mathrm{MeOH}(6 \mathrm{~mL})$, and water $(6 \mathrm{~mL})$. The resulting mixture was refluxed with stirring for $48 \mathrm{~h}$ under nitrogen atmosphere. Then the reaction mixture was concentrated under reduced pressure, diluted with water, and extracted with EtOAc. The extract was washed with brine, dried over $\mathrm{MgSO}_{4}$, and concentrated. The residue was purified by silica gel column chromatography (hexaneEtOAc in the gradient of polarity) to give $4(0.035 \mathrm{~g}, 14.6 \%)$ as a yellow solid.

- ${ }^{1} \mathrm{H}$ NMR (400 MHz, $\left.\mathrm{CDCl}_{3}\right) \delta$ (ppm): $\delta 9.97(\mathrm{~s}, 1 \mathrm{H})$, $8.20\left(\mathrm{dd}, J_{l}=8.00 \mathrm{~Hz}, J_{2}=12.8 \mathrm{~Hz}, 2 \mathrm{H}\right), 7.94-7.91(\mathrm{~m}$, $2 \mathrm{H}), 7.82(\mathrm{~d}, J=4.00 \mathrm{~Hz}, 2 \mathrm{H}), 7.74-7.71(\mathrm{~m}, 3 \mathrm{H}), 7.56$ $\left(\mathrm{dd}, J_{I}=1.20 \mathrm{~Hz}, J_{2}=1.2 \mathrm{~Hz}, 1 \mathrm{H}\right), 7.42-7.38(\mathrm{~m}, 6 \mathrm{H})$, $7.20\left(\mathrm{dd}, J_{l}=4.00 \mathrm{~Hz}, J_{2}=5.20 \mathrm{~Hz}, 1 \mathrm{H}\right)$.

- ${ }^{13} \mathrm{C}$ NMR $\left(151 \mathrm{MHz}, \mathrm{CDCl}_{3}\right) \delta$ (ppm): $\delta 182.5,155.3$, 153.7, 151.6, 141.2, 140.8, 138.9, 138.7, 138.3, 137.9, $132.8,132.3,130.4,130.3,129.7,129.5,129.2,128.7$, 128.6, 127.6, 127.2, 126.9, 126.6, 124.5, 124.0.

- $\mathbf{M S}(\mathrm{m} / \mathrm{z}):\left[\mathrm{M}^{+}\right] 475.0936$

- Elemental analysis: calc. (\%) C: 73.39; H: 3.82; N: 5.90; S: 13.51; found: C:73.34; H:3.80; N:5.87; S:13.47.
Preparation of 5-(8-(3,4-ethylenodioxythiophen-5-yl)-2,3-diphenylquinoxalin-5-yl)thiophene-2-carbaldehyde (5)

Bis(triphenylphosphine)palladium (II) dichloride $\left(\mathrm{PdCl}_{2}\left(\mathrm{PPh}_{3}\right)_{2}\right)(0.021 \mathrm{~g}, 0.0297 \mathrm{mmol})$ was added at room temperature under nitrogen atmosphere to a mixture of $\mathbf{3}$ $(0.07 \mathrm{~g}, 0.148 \mathrm{mmol})$ and 2-(tributylstannyl)ethylenodioxythiophene $(0.096 \mathrm{~g}, 0.22 \mathrm{mmol})$ in anhydrous THF $(20 \mathrm{~mL})$. The resulting mixture was refluxed with stirring for $72 \mathrm{~h}$. Then the reaction mixture was concentrated under reduced pressure, diluted with water, and extracted with EtOAc. The extract was washed with brine, dried over $\mathrm{MgSO}_{4}$, and concentrated. The residue was purified by silica gel column chromatography (hexane-EtOAc in the gradient of polarity) to give $5(0.027 \mathrm{~g}, 34.2 \%)$ as an orange solid.

- ${ }^{1} \mathbf{H}$ NMR (400 MHz, $\left.\mathrm{CDCl}_{3}\right) \delta(\mathrm{ppm}): \delta 9.96(\mathrm{~s}, 1 \mathrm{H})$, $8.68(\mathrm{~d}, J=8.40 \mathrm{~Hz}, 1 \mathrm{H}), 8.20(\mathrm{~d}, J=8.40 \mathrm{~Hz}, 1 \mathrm{H}), 7.92$ $(\mathrm{d}, J=4.00 \mathrm{~Hz}, 1 \mathrm{H}), 7.80(\mathrm{~d}, J=4.00 \mathrm{~Hz}, 1 \mathrm{H}), 7.75-7.70$ (m, 4H), 7.53-7.48(m, 2H), 7.41-7.37 (m, 4H), $6.62(\mathrm{~s}$, $1 \mathrm{H}), 4.44-4.42(\mathrm{~m}, 2 \mathrm{H}), 4.32-4.30(\mathrm{~m}, 2 \mathrm{H})$.

- ${ }^{13}$ C NMR (151 MHz, $\left.\mathrm{CDCl}_{3}\right) \delta$ (ppm): $\delta 181.6,158.3$, 155.5, 152.0, 149.7, 145.6, 139.2, 138.6, 137.9, 137.4, $132.9,131.7,131.5,129.4,128.7,128.3,127.8,127.5$, 114.3, 94.0, 93.8, 65.4 .

- $\mathbf{M S}(\mathrm{m} / \mathrm{z}):\left[\mathrm{M}^{+}\right] 533.0768$

- Elemental analysis: calc. (\%) C: 69.90; H: 3.78; N: 5.26; S: 12.04; found: C:69.94; H:3.82; N:5.31; S:12.09.

\section{Preparation of 2-cyano-3-(5-(8-(3,4-ethylenodioxythio- phen-5-yl)-2,3-diphenylquinoxalin-5-yl)thiophen-2-yl) acrylic acid (6)}

In a three-necked round bottom flask, $5(0.027 \mathrm{~g}, 0.051$ mmol) was dissolved in toluene $(20 \mathrm{~mL})$. Cyanoacetic acid $(0.013 \mathrm{~g}, 0.152 \mathrm{mmol})$ was added in an inert atmosphere of nitrogen. After $15 \mathrm{~min}$ piperidine $(0.0043 \mathrm{~g}, 0.051 \mathrm{mmol})$ was added. The resulting mixture was refluxed with stirring overnight. Then the reaction mixture was concentrated under reduced pressure, diluted with water, and extracted with EtOAc. The extract was washed with brine, dried over $\mathrm{MgSO}_{4}$, and concentrated. The residue was purified by silica gel column chromatography using dichloromethane-methanol $(95: 5)$ as the eluent to give $6(0.021 \mathrm{~g}, 70 \%)$ as a brown solid.

-1H NMR (400 MHz, $\left.\mathrm{CDCl}_{3}\right) \delta(\mathrm{ppm}): \delta 8.08(\mathrm{~s}, 1 \mathrm{H})$, 7.73-7.634 (m, 4H), 7.54-7.51 (m, 4H), 7.48-7.39 (m, $6 \mathrm{H}), 6.98(\mathrm{~s}, 1 \mathrm{H}), 4.27-4.24(\mathrm{~m}, 4 \mathrm{H})$.

-13 C NMR (151 MHz, $\mathrm{CDCl}_{3}$ ) $\delta$ (ppm): $\delta 158.7,154.2$, $151.3,150.1,145.3,138.7,137.5,130.3,129.7,128.5$, $127.4,127.3,117.5,114.1,93.1,92.8,65.0$. 
-MS (m/z): $\left[\mathrm{M}^{+}\right] 600.1036$

Elemental analysis: calc. (\%) C: 68.10; H: 3.53; N: 7.01; S: 10.69; found: C:68.07; H:3.50; N:7.00; S:10.67.

\section{Preparation of 2-cyano-3-(5-(2,3-diphe-} nyl-8-(thiophen-2-yl)quinoxalin-5-yl)thiophen-2-yl)acrylic acid (7)

In a three-necked round bottom flask, $5(0.035 \mathrm{~g}, 0.074$ $\mathrm{mmol})$ was dissolved in toluene $(20 \mathrm{~mL})$. Cyanoacetic acid $(0.019 \mathrm{~g}, 0.222 \mathrm{mmol})$ was added an in inert atmosphere of nitrogen. After $15 \mathrm{~min}$ piperidine $(0.0063 \mathrm{~g}, 0.074 \mathrm{mmol})$ was added. The resulting mixture was refluxed with stirring overnight. Then the reaction mixture was concentrated under reduced pressure, diluted with water, and extracted with EtOAc. The extract was washed with brine, dried over $\mathrm{MgSO}_{4}$, and concentrated. The residue was purified by silica gel column chromatography using dichloromethane-methanol $(95: 5)$ as the eluent to give $7(0.032 \mathrm{~g}, 50 \%)$ as a yellow solid.

-1H NMR (400 MHz, $\left.\mathrm{CDCl}_{3}\right) \delta(\mathrm{ppm}): \delta 8.25(\mathrm{~s}, 1 \mathrm{H})$, 8.21-8.14 (m, 2H), 7.91-7.87 (m, 2H), 7.83-7.80 (m, 2H), 7.78-7.73(m, 2H), 7.44-7.37 (m, 9H).

- ${ }^{13}$ C NMR $\left(151 \mathrm{MHz}, \mathrm{CDCl}_{3}\right) \delta(\mathrm{ppm}): \delta 159.8,154.8$, 149.6, 144.4, 139.8, 138.2, 137.5, 130.1, 129.2, 128.7, 127.5, 126.2, 117.7, 93.0.

-MS (m/z): $\left[\mathrm{M}^{+}\right] 542.0994$

-Elemental analysis: calc. (\%) C: 70.96; H: 3.54; N: 7.76; S: 11.84; found: C:70.94; H:3.51; N:7.72; S:11.81.

\section{Conclusions}

In summary, we designed, synthesized and characterized two 2,3-diphenylquinoxaline derivatives: 2-cyano-3-(5-(8-(3,4ethylenodioxythiophen-5-yl)-2,3-diphenylquinoxalin-5-yl) thiophen-2-yl)acrylic acid (6) and 2-cyano-3-(5-(2,3-diphenyl-8-(thiophen-2-yl)quinoxalin-5-yl)thiophen-2-yl)acrylic acid (7). This multi-step synthesis proceeded with good yield. The quantum-chemical results show the bipolar properties of the obtained systems, e.g. narrow energy gap (2.09 and $2.20 \mathrm{eV})$, low ionization potential $(-6.20$ and -6.45 $\mathrm{eV}$ ) and distribution of HOMO / LUMO orbitals. Moreover, experimental results on optical properties correlate well with the ab-initio study. They indicate good absorption in the visible light region $(380-550 \mathrm{~nm})$. Theoretical calculations show that 6 have the higher $\mathrm{V}_{\text {oc }}(0.96 \mathrm{eV}), \Delta G^{\text {inject }}$ $(-0.73 \mathrm{eV})$ than compound $7(0.84 \mathrm{eV},(-0.60 \mathrm{eV})$, thus the $\mathrm{e}^{-}$injection is more effective due to the higher excited state linked to the semiconductor conduction band edge. Consequently, compound $\mathbf{6}$ presents favorable properties to potential application to organic solar cells because of the relatively similar LHE, larger $\Delta G^{\text {inject }}$, and $V_{\text {oc }}$.

Supplementary Information The online version contains supplementary material available at https://doi.org/10.1007/s11664-021-09041-0.

Acknowledgments Calculations have been carried out using resources provided by Wroclaw Centre for Networking and Supercomputing (http://wcss.pl), Grant No. 93. We are thankful to Ph.D. P. SuchorskaWoźniak from Wrocław University of Science and Technology, Faculty of Microsystem Electronics and Photonics for absorption measurement.

Funding This research was funded by the National Science Centre, Poland, No. 2017/01/X/ST5/00340.

Conflict of interest The authors declare that they have no conflict of interest.

Open Access This article is licensed under a Creative Commons Attribution 4.0 International License, which permits use, sharing, adaptation, distribution and reproduction in any medium or format, as long as you give appropriate credit to the original author(s) and the source, provide a link to the Creative Commons licence, and indicate if changes were made. The images or other third party material in this article are included in the article's Creative Commons licence, unless indicated otherwise in a credit line to the material. If material is not included in the article's Creative Commons licence and your intended use is not permitted by statutory regulation or exceeds the permitted use, you will need to obtain permission directly from the copyright holder. To view a copy of this licence, visit http://creativecommons.org/licenses/by/4.0/.

\section{References}

1. K. Leo, Organic photovoltaics. Nat. Rev. Mater. 1, 16056 (2016). https://doi.org/10.1038/natrevmats.2016.56.

2. T.P. Osedach, T.L. Andrew, and V. Bulović, Energy Environ. Sci. 6, 711 (2013). https://doi.org/10.1039/C3EE24138F.

3. B. Lee, L. Lahann, Y. Lia, and S.R. Forrest, Sustain. Energ. Fuels. 4, 5765 (2020). https://doi.org/10.1039/D0SE00910E.

4. C.J. Brabec, J.A. Hauch, P. Schilinsky, and C. Waldauf, MRS Bull. 30, 50 (2005). https://doi.org/10.1557/mrs2005.10.

5. R. Xue, J. Zhang, Y. Li, and Y. Li, Small 14, 1801793 (2018). https://doi.org/10.1002/smll.201801793.

6. L. Zhan, S. Li, T.K. Lau, Y. Cui, X. Lu, M. Shi, C.Z. Li, H. Li, J. Hou, and H. Chen, Energy Environ. Sci. 1, 635 (2020). https:// doi.org/10.1039/C9EE03710A.

7. X. Yi, C.H.Y. Ho, B. Gautam, L. Lei, A.H. Chowdhury, B. Bahrami, Q. Qiaoc, and F. So, J. Mater. Chem. C 8, 16092 (2020). https://doi.org/10.1039/D0TC03969A.

8. T.M. Grant, K.L.C. Kaller, T.J. Coathup, N.A. Rice, and K. Hinzer, Org. Electron. 87, 105976 (2020). https://doi.org/10. 1016/j.orgel.2020.105976.

9. M.C. Heiber, A.A. Herzing, L.J. Richter, and D.M. DeLongchamp, J. Mater. Chem. C 8, 15339 (2020). https://doi.org/10. 1039/D0TC03087B.

10. K. Zhou, H. Dong, H.L. Zhang, and W. Hu, Phys. Chem. Chem. Phys. 16, 22448 (2014). https://doi.org/10.1039/C4CP01700E.

11. O.S. Kim, J.B. Kwon, S.W. Kim, B. Xu, K.H. Seo, C.E. Park, W.J. Do, J.H. Bae, and S.W. Kang, Polymers 11, 1818 (2019). https:// doi.org/10.3390/polym11111818. 
12. K.S. Keremane, R. Rao, and A.V. Adhikari, Photochem. Photobiol. (2020). https://doi.org/10.1111/php.13337.

13. S. Steinberger, A. Mishra, E. Reinold, C.M. Müller, C. Uhrich, M. Pfeiffer, and P. Bäuerle, Org. Lett. 13, 90 (2011). https://doi. org/10.1021/ol102603n.

14. T. Zhang, I.E. Brumboiu, C. Grazioli, A. Guarnaccio, M. Coreno, M. de Simone, A. Santagata, H. Rensmo, B. Brena, V. Lanzilotto, and C. Puglia, J. Phys. Chem. C 122, 17706 (2018). https://doi. org/10.1021/acs.jpcc.8b06475.

15. I. Maliszewsk Paczkowski, F. Lange Coelho, and L. Franciscato Campo, J. Mol. Liq. 319, 114277 (2020). https://doi.org/10.1016/j. molliq.2020.114277.

16. M.S. Abusaif, M. Fathy, M.A. Abu-Saied, A.A. Elhenawy, A.B. Kashyout, M.R. Selim, and Y.A. Ammar, J. Mol. Struct. 1225, 129297 (2021). https://doi.org/10.1016/j.molstruc.2020.129297.

17. J. Hou, H.Y. Chen, S. Zhang, G. Li, and Y. Yang, J. Am. Chem. Soc. 130, 16144 (2008). https://doi.org/10.1021/ja806687u.

18. J.T.E. Quinn, J. Zhu, X. Li, J. Wang, and Y. Li, J. Mater. Chem. C 5, 8654 (2017). https://doi.org/10.1039/c7tc01680h.

19. M.H. Yang, S.-J. Ko, N.G. An, D.R. Whang, S.-H. Lee, H. Ahn, J.Y. Kim, D. Vak, S.C. Yoon, and D.W. Chang, J. Mater. Chem. A 8, 25208 (2020). https://doi.org/10.1039/D0TA09354H.

20. X. Li, S. Cui, D. Wang, Y. Zhou, H. Zhou, Y. Hu, J.G. Liu, Y. Long, W. Wu, J. Hua, and H. Tian, Chemsuschem 7, 2879 (2014). https://doi.org/10.1002/cssc.201402414.

21. R.M. Kamble, B.K. Sharma, A.M. Shaikh, and S. Chacko, Chem. Select. 3, 6907 (2018). https://doi.org/10.1002/slct.201801208.

22. R. Pashazadeh, G. Sych, S. Nasiri, K. Leitonas, A. Lazauskas, D. Volyniuk, P.J. Skabara, and J.V. Grazulevicius, Chem. Eng. J. 401, 125962 (2020). https://doi.org/10.1016/j.cej.2020.125962.

23. X. Li, F. Yu, S. Stappert, C. Li, Y. Zhou, Y. Yu, X. Li, H. Agren, J. Hua, and H. Tian, ACS Appl. Mater. Interfaces 8, 19393 (2016). https://doi.org/10.1021/acsami.6b04007.

24. M.-L. Han, Y.-Z. Zhu, S. Liu, Q.-L. Liu, D. Ye, B. Wang, and J.-Y. Zheng, J. Power Sources 387, 117 (2018). https://doi.org/ 10.1016/j.jpowsour.2018.03.059

25. J. Zhang, H.-B. Li, S.-L. Sun, Y. Geng, Y. Wua, and Z.-M. Su, J. Mater. Chem. 22, 568 (2012). https://doi.org/10.1039/C1JM1 $3028 \mathrm{E}$

26. M.S. Abusaif, M.A. Abu-Saied, M. Fathy, A.A. El-Sherif, A.B. Kashyout, M.R. Selim, and Y.A. Ammar, J. Iran. Chem. Soc. (2020). https://doi.org/10.1007/s13738-020-02082-y.

27. D. Zając, J. Sołoducho, T. Jarosz, M. Łapkowski, and S. Roszak, Electrochim. Acta 173, 105 (2015). https://doi.org/10.1016/j.elect acta.2015.05.038.

28. D. Zając, J. Sołoducho, T. Jarosz, M. Łapkowski, and S. Roszak, Indian J. Appl. Res 6, 395 (2016).
29. D. Zając, J. Sołoducho, T. Jarosz, M. Łapkowski, and S. Roszak, Indian J. Appl. Res 7, 58 (2017).

30. J.B. Asbury, Y.Q. Wang, E. Hao, H. Ghosh, and T. Lian, Res. Chem. Intermed. 27, 393 (2001). https://doi.org/10.1163/15685 6701104202255.

31. R.G. Parr, and W. Yang, Density Functional Theory of Atoms and Molecules (New York: Oxford University Press, 1994).

32. A.D. Becke, J. Chem. Phys. 98, 5648 (1993). https://doi.org/10. 1063/1.464913.

33. C. Lee, W. Yang, and R.G. Parr, Phys. Rev. B. 37, 785 (1988). https://doi.org/10.1103/PhysRevB.37.785.

34. S.H. Vosko, L. Wilk, and M. Nusair, Can. J. Phys. 58, 1200 (1980). https://doi.org/10.1139/p80-159.

35. T.H. Dunning Jr., J. Chem. Phys. 90, 1007 (1989). https://doi.org/ 10.1063/1.456153.

36. E. Runge, and E.K.U. Gross, Phys. Rev. Lett. 52, 997 (1984). https://doi.org/10.1103/PhysRevLett.52.997.

37. Gaussian 16, Revision C.01, M. J. Frisch, G. W. Trucks, H. B. Schlegel, G. E. Scuseria, M. A. Robb, J. R. Cheeseman, G. Scalmani, V. Barone, G. A. Petersson, H. Nakatsuji, X. Li, M. Caricato, A. V. Marenich, J. Bloino, B. G. Janesko, R. Gomperts, B. Mennucci, H. P. Hratchian, J. V. Ortiz, A. F. Izmaylov, J. L. Sonnenberg, D. Williams-Young, F. Ding, F. Lipparini, F. Egidi, J. Goings, B. Peng, A. Petrone, T. Henderson, D. Ranasinghe, V. G. Zakrzewski, J. Gao, N. Rega, G. Zheng, W. Liang, M. Hada, M. Ehara, K. Toyota, R. Fukuda, J. Hasegawa, M. Ishida, T. Nakajima, Y. Honda, O. Kitao, H. Nakai, T. Vreven, K. Throssell, J. A. Montgomery, Jr., J. E. Peralta, F. Ogliaro, M. J. Bearpark, J. J. Heyd, E. N. Brothers, K. N. Kudin, V. N. Staroverov, T. A. Keith, R. Kobayashi, J. Normand, K. Raghavachari, A. P. Rendell, J. C. Burant, S. S. Iyengar, J. Tomasi, M. Cossi, J. M. Millam, M. Klene, C. Adamo, R. Cammi, J. W. Ochterski, R. L. Martin, K. Morokuma, O. Farkas, J. B. Foresman, and D. J. Fox, Gaussian, Inc., Wallingford CT (2016).

38. Gauss View, Version 6.1, R. Dennington, T. A. Keith, J. M. Millam, Semichem Inc., Shawnee Mission, KS (2016).

39. H.D. Weldekirstos, M.-C. Kuo, S.-R. Li, W.-L. Su, M.A. Desta, W.-T. Wu, C.-H. Kuo, and S.-S. Sun, Dyes Pigm. 163, 761 (2019). https://doi.org/10.1016/j.dyepig.2018.12.042.

Publisher's Note Springer Nature remains neutral with regard to jurisdictional claims in published maps and institutional affiliations. 